Vol. 17, $n^{\circ} 2 \mid 2013$

Varia

\title{
Griffiths (Paul), Lost Londons. Change, Crime and Control in the Capital City (1550-1660)
}

2008, Cambridge, Cambridge University Press, 544 pp., ISBN 97805218

85249

Eleni Liapi

\section{(2) OpenEdition}

\section{Journals}

Electronic version

URL: http://journals.openedition.org/chs/1450

DOI: $10.4000 /$ chs. 1450

ISSN: 1663-4837

\section{Publisher}

Librairie Droz

\section{Printed version}

Date of publication: 1 December 2013

Number of pages: 150-152

ISBN: 978-2-600-01776-3

ISSN: 1422-0857

\section{Electronic reference}

Eleni Liapi, «Griffiths (Paul), Lost Londons. Change, Crime and Control in the Capital City (1550-1660) ». Crime, Histoire \& Sociétés / Crime, History \& Societies [Online], Vol. 17, n² | 2013, Online since 10 December 2013, connection on 22 September 2020. URL : http://journals.openedition.org/chs/1450 DOI : https://doi.org/10.4000/chs. 1450

This text was automatically generated on 22 September 2020

(C) Droz 


\section{Griffiths (Paul), Lost Londons. Change, Crime and Control in the Capital City (1550-1660)}

2008, Cambridge, Cambridge University Press, 544 pp., ISBN 97805218

85249

Eleni Liapi

\section{REFERENCES}

Griffiths (Paul), Lost Londons. Change, Crime and Control in the Capital City (1550-1660), 2008, Cambridge, Cambridge University Press, 544 pp., ISBN 9780521885249.

1 Lost Londons marks a milestone in writing about early modern London. Utilizing comprehensive research in a variety of sources, it seeks to recapture the experience of living in London (from 1550 to 1660) in all its messy and sordid reality-or at least in the minds of those who had a reason to think of the city as a whole. This book will be unfairly treated if it is described as just the latest contribution to the historiographical debate about the stability of early modern London. Nonetheless, it does engage in the conversation between those who, like Steve Rappaport, Valerie Pearl and Ian Archer, argue that London weathered the storms of the sixteenth and seventeenth centuries successfully (emphasizing the cohesive role of administrative units such as parishes, guilds, companies and wards, as well as the diffusing of tensions by the shared citizen identity, by social mobility, and welfare) and those, like Paul Clark, Paul Slack and A.L. Beier, who paint a bleak picture of London teetering on the precipice of chaos, with extreme social and political polarization occasionally exploding in outbursts of disorder and riot.

2 Griffiths attempts to recast the debate, stressing the ambivalence of early modern London : his book describes equally a chaotic city and the elaborate efforts to organize and manage its unruly growth, but he does not wish to disentangle those two sides or 
reach a definitive conclusion. This stance stems from his different definition of stability: since 'the very idea of a stable city is a paradox', all the ruling bodies of London could hope for was to contain what Griffiths views as instability, namely 'the hum-drum urban cadence of vagrancy, theft or incessant "night battles"'. This treatment suggests that it might be time to move beyond the question of stability altogether.

One of Lost Londons major strengths is the comprehensive research on an impressive range of primary sources : even though Griffiths places most emphasis on Bridewell records (analyzing extensively the administrative jurisdiction and processes of London's first house of correction), he uses extensively various other sources, most importantly quarter sessions records and administrative records (the Repertories of the Court of Aldermen, the Journals of the Common Council, and parochial records). $\mathrm{He}$ employs them in order to corroborate his findings from Bridewell as well as to explore elite mentalities with regard to growth and its repercussions. Nevertheless, his reading of the Bridewell records informs the way in which his arguments about crime and policing in London are formed. This focus on Bridewell in conjunction with his almost exclusive examination of petty crime, while being a welcome addition to the scholarly treatment of crime in the metropolis, leads to a disproportionate emphasis on the authorities' initiative and agency in law enforcement.

4 Apart from the different scope of Lost Londons, Griffiths deviates from the previous literature of stability in that he does not mine the records in order to reconstruct social reality, but to explore the ways in which London was perceived or rhetorically constructed. In this respect, his work converses with recent literature about the metropolis such as Londinopolis and Imagining early modern London. This explains his emphasis on language, exploring how London was perceived through the terms used by the Corporation of London and the Crown (describing for example how London was 'swarming' with an 'extraordinary' number of vagrants), as well as how labels attached to criminals changed over time both as a result of evolving street talk and as a consequence of shifting legal language. This provides the reader with a better appreciation of how London and its disorderly subjects were viewed and constructed in elite discourses. Occasionally however Griffiths's language slips to that of description of actual phenomena, thus leaving the reader wondering whether what is narrated is viewed as historical reality or the rhetoric of London's administration.

5 The ambivalence of Lost Londons is intricately connected with Griffiths's argument that in this period both policing and criminal organization were more sophisticated that has been hitherto assumed. Even though it has often been argued (by scholars such as Malcolm Gaskill and A.L. Beier) that London's law enforcement was dependant on private initiative and thus inefficient, Griffiths stresses the various painstaking attempts by the City of London to manage the unprecedented growth of the city and argues that these were ever evolving and adapting to the changing circumstances with as much success as could be possibly expected. Sufficient numbers of law enforcement agents were active in London: constables, beadles, informers, bellmen, marshals and even aldermen deputies all contributed to keeping London adequately policed, and they performed their duties diligently and efficiently - even though Griffiths does not shy away from describing the criticism they received or allowing that part of it was doubtlessly justified. In addition, efforts were made to restrict unlawful movement and activities by improving the lighting of streets at night and building forms of record- 
keeping which would provide magistrates with knowledge of criminal techniques, identities and networks.

On the other hand Griffiths challenges the historiography (with representatives such as Paul Slack, James Sharpe and Linda Woodbridge) relating to rogue literature which has disqualified the claims of rogue pamphleteers that a criminal underworld was in existence. Going through the records, Griffiths has found instances of criminal team working, of criminal networks which used a distinctive jargon and nicknames and shared criminal techniques (especially in the case of recidivists, whose return to the courts threw light on associations created in prison and continued after their release). These findings seem to problematize the assumption that crime was disorganized and circumstantial. One thing that is not entirely clear from Griffiths's treatment of crime is whether or not he is describing a subculture : he states that the boundaries between criminals and citizens were rhetorically constructed in order to serve political goals and that citizens crossed them all the time, but when he is describing the sophistication of crime his phrasing suggests that he is describing a criminal underworld (using expressions such as 'talented thieves passed on skills' and 'thieves were drilled by seasoned artists'). In addition, it is not clear whether Griffiths accepts rogue literature as a trustworthy source; he seems to categorize it as part of the official discourses about crime (aiming to marginalize vagrants and other petty criminals) while at the same time he is adding it as further evidence for his arguments.

7 In general, Lost Londons is a masterfully written book which challenges many of the assumptions about early modern London and urban crime and suggests that the scholarship about order and crime can transcend the question of stability. The style of writing evokes perfectly the image of a city always in flux, moving, evolving, or spiraling out of control but always vibrant and exhilarating, even at its most heartbreaking moments.

\section{AUTHORS}

\section{ELENI LIAPI}

University of York

lena.liapi@york.ac.uk 